\title{
PKM PADA MASYARAKAT PETANI CAP TIKUS DI KELURAHAN TARATARA KECAMATAN TOMOHON BARAT KOTA TOMOHON
}

\author{
Theodorus Pangalila \\ Jurusan Pendidikan Pancasila dan Kewarganegaraan FIS Unima \\ Email: theopangalila@unima.ac.id
}

\begin{abstract}
ABSTRAK
Masyarakat kelurahan Taratara sebagain besar penduduknya berprofesi sebagai petani terutama petani cap tikus dan menggantungkan hidup mereka dari hasil penjualan cap tikus. Kendati demikian dalam kehidupan setiap hari para petani cap tikus ini menghadapi berbagai permasalahan seperti: (1). Tidak ada kelompok tani atau wadah yang mengontrol harga jual cap tikus, sehingga terjadi variasi harga per botol. (2). Belum ada wadah perkumpulan yang bisa memfasilitasi masyarakat pembuat cap tikus untuk menyimpan uang hasil penjualan cap tikus dan tempat peminjaman uang. (3). Banyak anak putus sekolah karena permasalahan biaya. Tujuan dilaksanakannya kegiatan ini adalah untuk memberdayakan kehidupan masyarakat petani cap tikus di Kelurahan Taratara agar dengan hasi yang mereka peroleh mereka dapat menunjang pendidikan anak-anak mereka sampai ke jenjan perguruan tinggi. Adapun kegiatan ini bermanfaat bagi para petani cap tikus dan menghasilkan luaran dalam bentuk artikel yang dipublikasikan dalam jurnal nasional.
\end{abstract}

Kata Kunci: Masyarakat, Petani, Cap Tikus, 


\section{PENDAHULUAN}

Taratara adalah salah satu kelurahan yang ada di kota Tomohon Sulawesi Utara. Nama Taratara berasal dari bunyi rumput taza-taza (tar-tar) yang jika dicabut akan mendengungkan bunyi tar-tar (cerita lainnya jenis bunga yang tumbuh di rawa-rawa dan kolam yang disebut taz-taz) (Kojongian, 2006:324). Kelurahan Taratara secara keseluruhan terdiri dari 4 kelurahan, yaitu Taratara, Taratara I, Taratara II dan Taratara III. Sebelum dimekarkan menjadi 4 kelurahan, awalnya Taratara hanya terbagi menjadi 2 desa, yaitu Taratara I dan Taratara II. Kelurahan Taratara terletak di bagian Barat Kota Tomohon. Kelurahan Taratara berada tepat di kaki gunung Lokon dan memiliki lahan perkebunan yang cukup luas. Tidak mengherankan jika sebagain besar masyarakat di Taratara menggantungkan hidup mereka pada sektor pertanian seperti menanam jagung dan padi. Di samping itu juga sebagaian besar masyarakat berprofesi sebagai pembuat cap tikus.

Di Taratara banyak ditumbuhi pohon enau yang menghasilkan air nira (saguer). Bahan dasar saguer biasanya oleh masyarakat sekitar disuling menjadi minuman cap tikus (minuman tradisional beralkohol tinggi) atau dibuat menjadi gula merah. Tomohon secara khusus Taratara memiliki sumber daya alam berupa pohon enau yang banyak dan dimanfaatkan oleh warga untuk membuat minuman beralkohol tradisional seperti saguer, sopi, dan cap tikus. Pengelolaan minuman beralkohol tersebut sudah menjadi mata pencaharian utama sebagian besar warga di Taratara.

Permasalahan di lapangan yang dihadapi oleh masyarakat petani cap tikus adalah berkaitan dengan peraturan atau regulasi dari pemerintah yang melarang peredaran cap tikus sebagai minuman beralkohal. Hal ini seperti yang diungkapkan oleh Roels (2018) yang mengatakan bahwa: "It highlights tensions between the widespread consumption of Cap Tikus in this particular locality and the wider problematization of alcohol in Indonesia-or more specifically, the growing systems of social control and modes of regulation around Cap Tikus." Permasalahan lainnya yang dihadapi petani cap tikus adalah harga per botol yang tidak menentu. Ada saat dimana kebutuhan pasar meningkat dan harga per botol mengalami peningkatan drastis, tetapi ada saat tertentu harga per botol menurun drastis. Sampai saat ini pun harga per botol cap tikus tidak ada keseragama harga antar petani cap tikus. Permasalahannya karena sampai saat ini belum pernah terbentuk kelompok tani pembuat cap tikus. Padahal jika mereka punya kelompok tani, mereka bisa mengatur patokan harga penjualan. Tidak ada perbedaan harga antara satu petani cap tikus dengan yang lainnya. Selanjutnya, banyak petani cap tikus yang mengeluh soal biaya pendidikan anak mereka karena kekurangan uang atau pendapatan tidak mencukupi untuk mengekolahkan anak. Oleh karena itu banyak anak usia sekolah yang terpaksa berhenti bersekolah karena alasan keuangan. Ada juga yang mampu menyekolahkan anak mereka sampai jenjang Sekolah Menengah Atas (SMA), tetapi tidak bisa melanjutkan pendidikan anak mereka ke jenjang Perguruan Tinggi. Padahal jika dikalkulasi petani cap tikus mempunyai pendapatan yang lumayan besar. Misalnya saja dengan haraga cap tikus per botol Rp. 15.000,dengan produksi 20 botol per hari, maka mereka memiliki pendapatan sebesar Rp. 300.000 per hari.

Mengingat kompleksnya permasalahan tersebut di atas dan disadari bahwa tidak semua permasalahan dapat diselesaikan sekaligus dalam kurun waktu tertentu maka berdasarkan justifikasi dan kesepakatan bersama dengan masyarakat mitra maka dipilih beberapa permasalahan prioritas yang harus diatasi, yaitu: Mitra 1 :

1. Tidak ada kelompok tani atau wadah yang mengontrol harga jual cap tikus, sehingga terjadi variasi harga per botol.

2. Belum ada wadah perkumpulan yang bisa memfasilitasi masyarakat pembuat cap tikus untuk menyimpan uang hasil penjualan cap tikus dan tempat peminjaman uang.

3. Banyak anak putus sekolah karena permasalahan biaya.

\section{TARGET LUARAN}

Luaran dalam kegiatan PKM ini ditargetkan adalah sebagai berikut:

a. Membentuk kelompok tani atau wadah yang mengontrol harga jual cap tikus, sehingga terjadi variasi harga per botol.

b. Membentuk wadah perkumpulan yang bisa memfasilitasi masyarakat pembuat cap tikus untuk menyimpan uang hasil 
penjualan cap tikus dan tempat peminjaman uang.

c. Mendorong para petani cap tikus untuk menyekolahkan anak mereka, bahkan sampai ke perguruan tinggi.

d. Laporan kegiatan dan artikel untuk dipublikasikan dalam Jurnal nasional.

\section{METODE PELAKSANAAN}

Bertolak dari permasalahan para petani Cap Tikus di Kelurahan Taratara sebagai kelompok mitra dan untuk menjawab permasalahan pertama; Tidak ada kelompok tani atau wadah yang mengontrol harga jual cap tikus, sehingga terjadi variasi harga per botol. Masalah ini akan diatasi dengan bekerjasama dengan pemerintah kelurahan untuk melakukan tindakan-tindakan kongkrit berupa:

a. Mengumpulkan data real masyarakat yang berprofesi sebagai petani cap tikus.

b. Mengumpulkan masyarakat petani cap tikus

c. Bersama pemerintah kelurahan mensosialisasikan pentingnya pembentukan wadah perkumpulan yang bisa mengontrol harga jual cap tikus.

d. Membentuk kelompok tani cap tikus Kelurahan Taratara.

Setelah adanya kesamaan persepsi antara pemerintah kelurahan Taratara dan para petani cap tikus, maka selanjutnya akan diadakan pelatihan dan pendampingan dalam pembentukan kelompok tani cap tikus.

Permasalahan kedua, Belum ada wadah perkumpulan yang bisa memfasilitasi masyarakat pembuat cap tikus untuk menyimpan uang hasil penjualan cap tikus dan tempat peminjaman uang. Setelah masalah pertama selesai dan terbentuk kelompok tani cap tikus di kelurahan Taratara, maka selanjutnya akan diberikan pembekalan bagaimana mengembangkan kelompok tani sebagai wadah untuk simpan pinjam bagi kelompok tani cap tikus.

Permasalahan ketiga, Banyak anak putus sekolah karena permasalahan biaya. Permasalahan ketiga ini akan diselesaikan dengan memberikan pemahaman kepada para orang tua khususnya petani cap tikus tentang pentingnya pendidikan pada anak. Selanjutnya akan diberikan pelatihan bagaimana mengatur keuangan berdasarkan pendapatan mereka sebagai petani cap tikus
Kegiatan dilaksanakan dalam bentuk ceramah, diskusi, dan praktek lapangan. Metode ceramah dan diskusi digunakan dalam mentransfer ilmu tentang pentingnya pembentukan kelompok tani dan wadah simpan pinjam uang bagi para petani cap tikus. Kemudian juga akan dijelaskan tentang bagaimana cara yang tepat untuk mengolah keuangan agar dapat mencukupi kebutuhan hidup setiap hari dan bagaimana mengumpulkan biaya untuk sekolah anak sampai ke jenjang perguruan tinggi.

Langkah yang akan dilakukan oleh tim kerja pelaksana PKM adalah melakukan persiapan yang diawali dengan pembahasan program dan langkah-langkah kerja tim mulai dari pembagian tugas dan tanggungjawab masing-masing anggota tim sampai dengan persiapan administrasi dan perangkat pendukung. Kegiatan lain yang masuk dalam persiapan adalah melakukan koordinasi dengan Lurah dan perangkat kelurahan untuk menyampaikan rencana pelaksanaan kegiatan PKM. Persiapan selanjutnya secara bersama tim kerja menyusun draft instrumen yang akan digunakan sebagai acuan dalam menjaring informasi atau data akurat tentang permasalahan mendasar mitra. Dengan demikian Instrumen yang disusun mencakup identifikasi atau penjaringan informasi permasalahan mendasar yang harus dipahami secara bersama sebelum mengawali kegiatan PKM ini antara lain adalah mengidentifikasi dan mempertajam serta menganalisis kembali faktor-faktor penyebab kedua permasalahan pokok di atas, juga mendapatkan informasi dan persepsi para petani cap tikus di Kelurahan Taratara mengenai permasalahan dan akar permasalahan yang dihadapi serta program yang ditawarkan dan langkah yang akan dilakukan untuk mengatasi permasalahan terutama yang berkaitan dengan upaya mengatasi permasalahan keuangan dan banyaknya anak yang putus sekolah. Hasil identifikasi tersebut di samping menjadi dasar penyusunan rencana kerja sekaligus sebagai landasan pelaksanaan kegiatan PKM. Langkah persiapan yang lainnya adalah pemantapan pemahaman atau penyamaan persepsi tentang program yang akan dijalankan oleh tim itu sendiri serta persiapan dan pengadaan materi yang akan digunakan dalam pelaksanaan kegiatan PKM.

Pelaksanaan kegiatan PKM pada masyarakat ini rencananya akan dilaksanakan 
selama 1 bulan, namun jika hasil kegiatan belum menampakkan hasil yang signifikan, maka akan dilanjutkan dengan kegiatan tambahan untuk lebih memantapkan hasil PKM.

\section{HASIL DAN PEMBAHASAN}

Pelaksanaan kegiatan PKM pada masyarakat petani cap tikus di kelurahan Taratara Kecamatan Tomohon Barat kota Tomohon dengan bentuk kegiatan penyuluhan dan pembinaan kepada para petani cat tikus sudah berjalan dengan baik. Berikut ini penjelasan hasil kegiatan PKM yang dituangkan dalam bentuk hasil kegiatan sebagai berikut:

\section{Hasil Kegiatan \\ Perencanaan}

Kegiatan-kegiatan yang dilakukan pada tahap perencanaan bisa dideskripsikan sebagai berikut:

a. Pembahasan Program Kegiatan

Persiapan yang diawali dengan pembahasan program dan langkah-langkah kerja tim mulai dari pembagian tugas dan tanggungjawab masing-masing anggota tim sampai dengan persiapan administrasi dan perangkat pendukung. Kegiatan lain yang masuk dalam persiapan adalah melakukan koordinasi dengan kepaka sekolah untuk menyampaikan rencana pelaksanaan kegiatan PKM. Kegiatan pembahasan program ini dilaksanakan pada bulan April 2018. Pada kesempatan ini tim pelaksana bertemu dengan Lurah Kelurahan Taratara beserta perangkat kelurahan untuk meminta persetujuan tentang kegiatan PKM yang akan dilaksanakan. Setelah disetujui kemudian tim menjelaskan secara rinci maksud dan tujuan pelaksanaan PKM pada masyarakat petani cap tikus di kelurahan Taratara Kecamatan Tomohon Barat kota Tomohon.

\section{b. Penyusunan Draft Instrumen}

Persiapan selanjutnya secara bersama tim kerja menyusun draft instrumen yang akan digunakan sebagai acuan dalam menjaring informasi atau data akurat tentang permasalahan mendasar mitra. Kegiatan ini dilaksanakan pada bulan Mei 2018. Instrumen yang disusun mencakup identifikasi atau penjaringan informasi permasalahan mendasar yang harus dipahami secara bersama sebelum mengawali kegiatan PKM ini antara lain adalah mengidentifikasi dan mempertajam serta menganalisis kembali faktor-faktor penyebab kedua permasalahan pokok di atas, juga mendapatkan informasi dan persepsi para petani cap tikus di Kelurahan Taratara mengenai permasalahan dan akar permasalahan yang dihadapi serta program yang ditawarkan dan langkah yang akan dilakukan untuk mengatasi permasalahan terutama yang berkaitan dengan upaya mengatasi permasalahan banyaknya anak putus sekolah karena persoalan biaya. Hasil identifikasi tersebut di samping menjadi dasar penyusunan rencana kerja sekaligus sebagai landasan pelaksanaan kegiatan PKM.

c. Penyusunan Program Pelatihan

Berdasarkan hasil indentifikasi tentan permasalahan yang ada di lapangan selanjutnya disusun program pelatihan. Dalam kegiatan ini dilakukan pemantapan pemahaman atau penyamaan persepsi tentang program yang akan dijalankan oleh tim itu sendiri dengan kepala sekolah dan para guru serta persiapan dan pengadaan materi yang akan digunakan dalam pelaksanaan kegiatan PKM.

\section{Pelaksanaan Kegiatan}

Pelaksanaan kegiatan IbM dilaksanakan selama dua hari, yakni tanggal 12-13 Oktober 2018. Hari pertama, tanggal 12 Oktober kegiatan difokuskan pada pemberian materi tentang profil petani cap tikus dan permasalahannya. Kegaitan ini dihadiri oleh 24 orang petani cap tikus dan perangkat kelurahan. Untuk sesi pertama disajikan dan dijelaskan tentang profil petani cap tikus dan perhitungan hasil usaha per bulan. Setelah itu para peserta diberikan waktu untuk istirahat. Selanjutnya dalam sesi kedua dijelaskan tentang bagiamana cara mengatur keuangan serta bagaimana membentuk kelompok tani cap tikus yang bisa mewadahi kegiatan simpan pinjam anggota kelompok tersebut. Dalam kegiatan hari pertama ini para peserta kelihatan begitu antusias dalam mengikuti setiap materi yang disajikan.

Pelaksanaan kegiatan hari kedua dilaksanakan pada tanggal 13 Oktober 2018. Kegiatan PKM pada hari kedua difokuskan pada penjelasan dan penguatan tentang peran orang tua dalam pendidikan anak-anak terutama dalam rangkah melanjutkan pendidikan sampai ke jenjang perguruan tinggi, di samping itu dijelaskan pula tentang prosuder pendaftaran mahasiswa di Universitas Negeri Manado dan beasiswa yang tersedia untuk warga masyarakat yang kurang mampu.

\section{Observasi dan Evaluasi}


Kegiatan selanjutnya yang dilakukan tim PKM adalah melakukan observasi dan evaluasi. Observasi dilakukan tim terhadap seluruh proses kegiatan mencakup proses pemberian materi dan perhitungan anggaran pendapatan dan tabungan untuk uang kuliah anak. Hal-hal pokok lainnya yang diobservasi oleh teim adalah kendalakendala dan kesulitan-kesulitan yang dihadapi oleh para petani cap tikus dalam mengelolah keuangan dan permasalahan yang dihadapi ketika hendak memasukkan anak mereka ke perguruan tinggi.

Evaluasi dilakukan oleh tim terhadap bagaimana para petani cap tikus mengelolah keuangan mereka dan berapa besar dana yang mereka sisihkan untuk biaya pendidikan anakanak mereka. Evaluasi dilakukan dengan berdasarkan hasil observasi yang telah dilakukan oleh tim. Dari hasil evaluasi tersebut kemudian oleh tim diberikan masukan dan koreksi terhadap hal-hal yang dianggap masih kurang dipahami oleh para petani cap tikus.

\section{Refleksi}

Refleksi dalam kegiatan PKM pada masyarakat petani cap tikus di Kelurahan Taratara ini dilakukan dengan tujuan untuk mengetahui kelebihan dan kekurangan yang muncul dalam proses pelaksanaan kegaitan ini. Hal ini dilakukan untuk menemukan rekomendasi yang cocok bagi pengembangan kegiatan selanjutnya. Hasil refleksi menjadi penting, karena lewat refleksi hasil kegiatan, para guru menyadari kekurangan dan kelebihannya masing-masing dan berusaha memperbaiki dalam proses kegiatan selanjutnya.

\section{KESIMPULAN}

Hasil yang dicapai melalui kegiatan PKM pada masyarakat petani cap tikus di Kelurahan Taratara Kecamatan Tomohon Barat Kota Tomohon bisa disimpulkan sebagai berikut:

1. Ada antusias yang tinggi dari para petani cap tikus dalam perhitungan penghasilan cap tikus setiap bulannya.

2. Terdapat peningkatan pemahanan dan kesadaran akan pentingnya pendidikan anak sampai ke jenjang perguruan tinggi.

\section{DAFTAR PUSTAKA}

Kojongan, A. 2006. Tomohon, Kotaku. Tomohon: Cv. Agape,

NN. 2016. Cap tikus. Onlin: https://id.wikipedia.org/wiki/Cap_tikus

NN. 2015. Permintaan Cap Tikus di Gorontalo dan Sulteng Meningkat. Online: https://www.seputarsulut.com/tag/petani -cap-tikus/

Roels, N. I. 2008. Reinventing drinking traditions in North Sulawesi. Online: https://chemicalyouth.org/projects/drink ing-cultures-north-sulawesi (Diakses: 10 Oktober 2018). 